\title{
PENINGKATAN KEMAMPUAN MEMBACA PERMULAAN MELALUI PENERAPAN METODE SAS (STRUKTURAL ANALITIK SINTETIK) ANAK USIA 5-6 TAHUN DI TK TAMAN HARAPAN
}

\author{
Rosni \\ Surel: rosni@gmail.com
}

\begin{abstract}
ABSTRAK
Penelitian ini bertujuan untuk mengetahui peningkatan kemampuan membaca permulaan anak usia 5-6 tahun melalui penerapan metode SAS (Struktural Analitik Sintetik) di TK Taman Harapan Medan. Jenis penelitian ini adalah penelitian tindakan kelas. Subjek penelitian anak kelompok B yang berjumlah 14 orang anak. Hasil observasi pada siklus I diketahui dari 14 orang anak secara klasikal terdapat 11 orang anak (79\%) tergolong mulai berkembang, dan 3 orang anak (21\%) tergolong berkembang sesuai harapan. Nilai rata-rata kemampuan membaca permulaan anak yaitu 48,21. Pada siklus II diketahui bahwa peningkatan kemampuan membaca permulaan anak meningkat yaitu 36\% (5 orang anak) berkembang sangat baik, 43\% (6 orang anak) berkembang sesuai harapan dan (3 orang anak) $21 \%$ mulai berkembang. Nilai rata-rata kemampuan membaca permulaan anak yaitu 70,53 dan kemampuan klasikal anak sebesar 79\%. Dengan demikian, dapat disimpulkan bahwa metode SAS dapat meningkatkan kemampuan membaca permulaan anak usia 5-6 tahun di Tk Taman Harapan Medan T.A 2015/2016.
\end{abstract}

Kata Kunci: Anak. Kemampuan Membaca Permulaan, Metode SAS

\section{PENDAHULUAN}

Pengembangan kemampuan berbahasa pada bagi anak usia Taman Kanak-kanak belajar membaca itu penting, anak-anak yang gemar membaca akan mempunyai rasa kebahasaan yang tinggi. Mereka akan berbicara, menulis dan memahami gagasan-gagasan rumit secara lebih baik. Kegemaran membaca permulaan harus dikembangkan sejak usia dini, anak yang sudah memiliki kesiapan membaca di Taman KanakKanak lebih percaya diri dan penuh kegembiraan. Menurut Firmanawaty (2004:13) ada beberapa manfaat yang diperoleh anak dari kegiatan membaca, yaitu :1) anak akan memperoleh pengetahuan; 2) anak dapat mengidentifikasikan dirinya; 3)

\begin{abstract}
anak menemukan nilai-nilai keutamaan untuk membina kepribadian; 4) Anak dapat berimajinasi dengan baik; 5) anak terbantu untuk menyelesaikan problem yang harusdihadapi; 6) anak dapat mengetahui pengalaman dan kebudayaanlain; 7) memupuk rasa percaya diri anak.

Peneliti sebagai guru di TK Taman Harapan mendapati bahwa kemampuan anak dalam kegiatan membaca dini ditemukan rendahnya kemampuan membaca permulaan. Dalam hal ini sebagian besar anak belum mampu membaca permulaan tetapi hanya menghafal saja. Hal ini ditandai dengan kondisi anak dari 14 orang anak kelompok B TK Taman Harapan yang mampu membaca
\end{abstract}


permulaan hanya 4 orang anak atau hanya sekitar $29 \%$ saja. Rendahnya kemampuan membaca permulaan disebabkan karena metode pembelajaran yang digunakan oleh guru tidak bervariasi atau monoton sehingga anak mengalami kebosanan. Kegiatan membaca dini belum terlihat pencapaian yang maksimal karena para guru belum menemukan cara yang terbaik untuk meningkatkan kemampuan membaca yang sesuai dengan kebutuhan dan perkembangan anak, agar anak tidak tertekan dalam kegiatan mengenal baca kata sehingga anak dapat menyenangi kegiatan membaca dini.

Berdasarkan kondisi tersebut untuk membuat anak menyenangi kegiatan membaca dini tanpa membuat anak tertekan maka disepakati bersama untuk meningkatkan kemampuan membaca permulaan di TK Taman Harapan akan dilaksanakan menggunakan metode SAS (Struktural Analitik Sintetik). Penggunaan metode SAS dalam pembelajaran membaca permulaan di TK merupakan salah satu alternatif dalam membantu atau membimbing anak ke arah penemuan sendiri, yaitu dengan menggunakan bantuan alat peraga/media. Pembelajaran bahasa sejak dini memang tidak dapat diabaikan begitu saja, yaitu seharusnya dimulai pada usia dini. Pembelajaran ini merupakan sarana yang strategis sebagai awal dalam memperoleh pengetahuan tentang kata, dan kalimat selanjutnya dapat berkembang terus sejalan dengan pertumbuhan dan perkembangan daya nalar anak.

Menurut Surya (dalam ssurya62.blogspot.com) bahwa dalam penerapannya, metode SAS menempuh langkah-langkah:

1. Guru bercerita atau tanya jawab dengan murid disertai gambar.

2. Membaca beberapa gambar, misalnya: gambar ibu, ayah, Nana, dsb.

3. Membaca beberapa kalimat dengan gambar, misalnya di bawah ini gambar seorang ibu terdapat bacaan "ini mama mami".

4. Setelah hafal, dilanjutkan membaca tanpa bantuan gambar. Misalnya: ini mama Noni, ini nana.

Menganalisis sebuah kalimat menjadi kata, suku kata, dan huruf kemudian mensinteskannya kembali menjadi kalimat.

Berdasarkan latar belakang masalah, dapat dikaji adapun permasalahan yang dirumuskan sebagai berikut:Apakah dengan penerapan metode SAS (struktural analitik sintetik) dapat meningkatkan kemampuan membaca permulaan anak usia 5-6 tahun di TK Taman Harapan tahun ajaran 2015/2016?

Merujuk pada rumusan masalah di atas, maka tujuan dilaksanakan penelitian ini adalah untuk meningkatkan kemampuan membaca permulaan anak usia 5-6 tahun melalui penerapan metode sas (struktural analitik sintetik) di TK Taman Harapan tahun ajaran 2015/2016. 


\section{METODE PENELITIAN}

Penelitian ini dilakukan di TK Taman Harapan Jl. Ibrahim Umar No. 11 Medan Tahun Ajaran 2015/2016dan waktu penelitian direncanakan selama 4 Bulan (Maret 2016 s/d Juni 2016).

Subjek dalam penelitian ini adalah anak usia 5-6 tahun di Kelompok B TK Taman Harapan Medan yang berjumlah 14 orang anak pada tahun ajaran 2015/2016.
Pengumpulan data dilakukan dengan mengggunakan Observasi, yaitu teknik yang dilakukan dengan cara pengamatan secara teliti dan sistematis. Observasi dilakukan untuk mendapatkan gambaran secara langsung peningkatan bahasa anak. Adapun indikator bahasa anak yang diamati dan ditingkatkan dapat dilihat pada tabel berikut:

Tabel 1. Kisi-kisi Lembar Observasi Kemampuan Membaca Permulaan Anak Usia 5-6 Tahun

\begin{tabular}{|c|c|c|c|c|c|}
\hline \multirow{2}{*}{ No } & \multirow{2}{*}{ Aspek Perkembangan } & \multicolumn{4}{|c|}{ Kriteria Penilaian } \\
\hline & & BSB & BSH & MB & BB \\
\hline 1. & $\begin{array}{l}\text { Menyebutkan simbol- } \\
\text { simbol huruf yang } \\
\text { dikenal }\end{array}$ & & & & \\
\hline 2. & $\begin{array}{l}\text { Menyebutkan } \\
\text { kelompok gambar } \\
\text { yang memiliki bunyi/ } \\
\text { huruf awal yang sama }\end{array}$ & & & & \\
\hline 3. & $\begin{array}{l}\text { Memahami hubungan } \\
\text { antara bunyi dan } \\
\text { bentuk huruf }\end{array}$ & & & & \\
\hline 4. & Membaca nama sendiri & & & & \\
\hline
\end{tabular}

Penelitian ini menggunakan desain model Arikunto (2012:16). Rancangan masing-masing siklus terdiri dari empat tahap yaitu perencanaan, pelaksanaan, pengamatan dan refleksi.

Analisa ini dilakukan untuk mengetahui berhasil atau tidaknya tindakan yang dilakukan dalam penelitian ini.Analisis lembar observasi untuk mengetahui peningkatan bahasa anak. Pemaparan data dilakukan dengan mencari persentase peningkatan bahasa pada anak secara individu atau perorangan dengan rumus Sujino (dalam Tarigan,2011) yaitu :

$$
\mathrm{Pi}=\frac{f}{n} \times 100 \%
$$

Dimana :

$\mathrm{Pi}=$ Persentase peningkatan bahasa pada anak.

$\mathrm{f}=$ jumlah skor yang diperoleh

$\mathrm{n}=$ jumlah skor keseluruhan

Dimana kriteria penilaian yang digunakan yaitu: 
Tabel 2. Kriteria Penilaian

\begin{tabular}{|c|c|}
\hline Prestasi & Keterangan \\
\hline $80 \%-100 \%$ & Berkembang Sangat \\
$60 \%-79 \%$ & Baik \\
$30 \%-59 \%$ & Berkembang Sesuai \\
$10 \%-29 \%$ & Harapan \\
& Mulai Berkembang \\
& Belum Berkembang \\
\hline
\end{tabular}

Adaptasi: Aqib (2011:41) dan Permen No. 58 Tahun 2009

\section{HASIL DAN PEMBAHASAN \\ Siklus I}

Sebelum melakukan tindakan siklus I, peneliti telah menyusun perencanaan pembelajaran yang akan dilaksanakan di dalam kelas, antara lain:

1. Peneliti dan observer secara kolaboratif merencanakan pembelajaran.

2. Peneliti membuat rencana pelaksanaan kegiatan.

3. Peneliti menyusun Rencana Kegiatan Harian (RKH) dengan Tema Alat Komunikasi.

4. Mempersiapkan bahan/media yang akan digunakan pada kegiatan pembelajaran.

5. Membuat lembar observasi

Pada tahap ini kegiatan yang akan dilakukan adalah melaksanakan penelitian sesuai dengan rencana penelitian dengan mengutamakan tindakan yang akan dilaksanakan yaitu meningkatkan kemampuan bahasa anak usia 5-6 tahun melalui permainan kartu bergambar.

1. Peneliti bersama observer masuk kedalam kelas memberikan salam dan membaca doa mau belajar.

2. Menyanyikan beberapa lagu yang berhubungan dengan tema yang akan diajarkan.
3. Pertemuan pagi.

4. Melakukan kegiatan pembuka sesuai dengan tema.

5. Menyampaikan dan menjelaskan kegiatan pembelajaran yang akan dikerjakan anak.

6. Pembelajaran dengan SAS:

a. Guru menyebutkan kalimat yang ada pada gambar.

b. Anak mengulang kalimat tersebut.

c. Anak menyebutkan setiap kata yang ada pada gambar.

d. Anak menyebutkan setiap huruf yang ada pada gambar.

e. Anak mengulang kembali setiap kata yang ada pada gambar.

f. Anak mengulang kembali kalimat yang ada pada gambar.

7. Istirahat/ makan.

8. Evaluasi kegiatan yang telah dilakukan.

9. Bernyanyi, doa mau pulang dan salam.

Selama proses pembelajaran meningkatkan kemampuan membaca permulaan anak dengan metode SAS, peneliti mengamati aktivitas anak dengan menggunakan lembar observasi yang telah dipersiapkan. Pelaksanaan penelitian dilakukan oleh peneliti dan dibantu oleh guru kelas. Dari hasil pengamatan yang dilakukan pada siklus I dengan dua kali pertemuan, diketahui bahwa tindakan yang dilakukan peneliti belum optimal dalam meningkatkan kemampuan membaca permulaan anak.ini terlihat pada tabel berikut: 
Tabel 3. Data Peningkatan Kemampuan Membaca Permulaan Anak Pada Siklus I

\begin{tabular}{|c|c|c|c|c|}
\hline No & Kode Anak & Skor & $\ddot{X}$ & Ket \\
\hline 1. & 1. & 6 & 37,5 & MB \\
\hline 2. & 2. & 8 & 50 & MB \\
\hline 3. & 3. & 7 & 43,75 & MB \\
\hline 4. & 4. & 10 & 62,5 & BSH \\
\hline 5. & 5. & 7 & 43,75 & MB \\
\hline 6. & 6. & 8 & 50 & MB \\
\hline 7. & 7. & 10 & 62,5 & BSH \\
\hline 8. & 8. & 8 & 50 & MB \\
\hline 9. & 9. & 6 & 37,5 & MB \\
\hline 10. & 10. & 7 & 43,75 & MB \\
\hline 11. & 11. & 6 & 37,5 & MB \\
\hline 12. & 12. & 8 & 50 & MB \\
\hline 13. & 13. & 10 & 62,5 & BSH \\
\hline 14. & 14. & 7 & 43,75 & MB \\
\hline \multicolumn{2}{|r|}{ Jumlah } & \multicolumn{6}{c|}{} & MB \\
\hline
\end{tabular}

Berdasarkan hasil observasi yang telah dilakukan selama siklus I dapat dilihat bahwa melalui metode SAS, belum dapat meningkatkan kemampuan membaca permulaan anak secara optimal.Dimana pada siklus I, peningkatan kemampuan membaca permulaan anak masih tergolong rendah.

Berdasarkan hasil observasi pada siklus I, analisis penyebab utama yaitu:

1. Masih terdapat anak yang belum mampu mengenal huruf dengan baik.

2. Masih terdapat anak yang belum mengenal gambar dan belum dapat menyebutkan simbol huruf di dalam kartu. Oleh karena itu, peneliti harus mampu menjelaskan dan menstimulasi anak agar mampu mengemukakan gambar yang didapatkannya.

3. Dalam menyampaikan penjelasan metode SAS, harus lebih
4. memperhatikan apakah anak sudah paham dengan penjelasan guru tentang metode tersebut.

5. Peneliti harus lebih memperhatikan dan memotivasi anak.

Peneliti menyajikan kartu katau gambar yang lebih menarik dari kartu sebelumnya untuk menarik perhatian anak.

\section{Siklus II}

Berdasarkan hasil refleksi Siklus I yang telah dilaksanakan selama dua kali pertemuan, maka di peroleh hasil bahwa peningkatan kemampuan membaca permulaan anak masih tergolong mulai berkembang, untuk itu penelitian ini dilanjutkan ke siklus II. Tahap perencanaan siklus II meliputi kegiatan:

1. Guru dan peneliti secara kolaboratif merencanakan pembelajaran. 
2. Peneliti membuat rencana pelaksanaan kegiatan.

3. Menyusun Rencana Kegiatan Harian (RKH).

4. Mempersiapkan media pembelajaran berupa kartu kata dan gambar yang lebih besar dan berwarna sehingga anak lebih tertarik dan semangat dalam mengikuti pembelajaran.

5. Membuat lembar observasi.

Pelaksanaan tindakan siklus II dilaksanakan selama dua kali pertemuan.Pada kegiatan ini, yang dilaksanakan adalah berupa perbaikan dari siklus I.

1. Peneliti bersama observer masuk kedalam kelas memberikan salam dan membaca doa mau belajar.

2. Menyanyikan beberapa lagu yang berhubungan dengan tema yang akan diajarkan.

3. Pertemuan pagi.

4. Melakukan kegiatan pembuka sesuai dengan tema.

5. Menyampaikan dan menjelaskan kegiatan pembelajaran yang akan dikerjakan anak.

6. Pembelajaran dengan SAS: a. Guru menyebutkan kalimat yang ada pada gambar.

b. Anak mengulang kalimat tersebut.

c. Anak menyebutkan setiap kata yang ada pada gambar.

d. Anak menyebutkan setiap huruf yang ada pada gambar.

e. Anak mengulang kembali setiap kata yang ada pada gambar.

f. Anak mengulang kembali kalimat yang ada pada gambar

7. Istirahat/ makan.

8. Evaluasi kegiatan yang telah dilakukan.

9. Bernyanyi, doa mau pulang dan salam.

Selama proses pembelajaran pada penggunaan metode SAS, peneliti dan observer sebagai mitra kolaborasi ikut secara bersama-sama mengamati aktivitas anak pada siklus ke II dan mengisi lembar observasi yang telah disediakan. Secara ringkas, hasil pengamatan peningkatan kemampuan membaca permulaan anak selama siklus II disajikan pada tabel 4.3 berikut ini:

Tabel 4. Data Peningkatan Kemampuan Membaca Permulaan Anak Pada Siklus II

\begin{tabular}{|c|c|c|c|c|}
\hline No & Kode Anak & Skor & $\mathbf{X}$ & Ket \\
\hline 1. & 1. & 10 & 62,5 & BSH \\
\hline 2. & 2. & 13 & 81,25 & BSB \\
\hline 3. & 3. & 9 & 56,25 & MB \\
\hline 4. & 4. & 11 & 68,75 & BSH \\
\hline 5. & 5. & 13 & 81,25 & BSB \\
\hline 6. & 6. & 10 & 62,5 & BSH \\
\hline 7. & 7. & 11 & 68,75 & BSH \\
\hline 8. & 8. & 9 & 56,25 & MB \\
\hline 9. & 9. & 13 & 81,25 & BSB \\
\hline
\end{tabular}




\begin{tabular}{|c|c|c|c|c|}
\hline 10. & 10. & 10 & 62,5 & $\mathrm{BSH}$ \\
\hline 11. & 11. & 11 & 68,75 & BSH \\
\hline 12. & 12. & 14 & 87,5 & $\overline{B S B}$ \\
\hline 13. & 13. & 15 & 93,75 & $\overline{B S B}$ \\
\hline 14. & 14. & 9 & 56,25 & MB \\
\hline \multicolumn{2}{|c|}{ Jumlah } & \multicolumn{2}{|c|}{987,5} & \multirow{2}{*}{ BSH } \\
\hline \multicolumn{2}{|c|}{ Rata-rata } & \multicolumn{2}{|c|}{70,53} & \\
\hline
\end{tabular}

Berdasarkan hasil observasi yang dilakukan oleh guru selaku mitra kolaborasi, di peroleh bahwa aktivitas yang dilakukan peneliti selama melaksanakan tindakan siklus II sudah tergolong baik.Setelah dilakukan analisis dan refleksi siklus II, diperoleh kesimpulan bahwa metode SAS dapat meningkatkan kemampuan membaca permulaan anak 5-6 Tahun di TK Taman Harapan.

\section{Pembahasan Penelitian}

Metode SAS (Struktural Analitik Sintetik) yang dilaksanakan di kelompok B pada anak usia 5-6 tahun di TK Taman Harapan merupakan penelitian tindakan yang bertujuan untuk meningkatkan kemampuan membaca permulaan anak. Penelitian ini dilaksanakan selama dua kali siklus, masingmasing siklus dilaksanakan dua kali pertemuan.

Metode SAS (Struktural Analitik Sintetik) terbukti dapat meningkatkan kemampuan membaca permulaan anak.Anak dapat gambar yang disediakan. Dari table 3.dapat diketahui bahwa pada siklus I di peroleh nilai rata-rata kemampuan

membaca permulaan anak 48,2. Pada gambar 4.1.menunjukkan bahwa pada siklus I, peningkatan kemampuan membaca permulaan anak sebagai berikut: 11 orang anak (79\%) tergolong mulai berkembang, dan 3 orang anak (21\%) tergolong berkembang sesuai harapan.

Sementara itu pada tabel 4. dapat dilihat bahwa pada siklus II diperoleh nilai rata-rata anak 70,53 dimana pada gambar 4.2 menunjukkan bahwa hingga pertemuan kedua pada siklus II, peningkatan kemampuan membaca permulaan anak berada pada kategori: $36 \%$ (5 orang anak) berkembang sangat baik, $43 \%$ (6 orang anak) berkembang sesuai harapan dan (3 orang anak) $21 \%$ mulai berkembang. Untuk lebih jelasnya, maka peningkatan dari siklus I sampai siklus II dapat dilihat pada tabel berikut ini:

Tabel 5. Rangkuman Peningkatan Kemampuan Membaca

Permulaan Anak Pada Siklus I dan II

\begin{tabular}{|l|c|c|c|c|c|c|}
\hline \multirow{2}{*}{ No } & \multirow{2}{*}{$\begin{array}{c}\text { Tingkat } \\
\text { Keberhasilan }\end{array}$} & Kategori & \multicolumn{2}{|c|}{ Siklus I } & \multicolumn{2}{|c|}{ Siklus II } \\
\cline { 4 - 7 } & & & F & $\%$ & F & $\%$ \\
\hline 1 & $80-100$ & BSB & 0 & 0 & 5 & 36 \\
\hline
\end{tabular}




\begin{tabular}{|c|c|c|c|c|c|c|}
\hline 2 & $60-79$ & BSH & 3 & 21 & 6 & 43 \\
\hline 3 & $30-59$ & MB & 11 & 79 & 3 & 21 \\
\hline 4 & $10-29$ & BB & 0 & 0 & 0 & 0 \\
\hline 5 & Jumlah & 14 & $\begin{array}{c}10 \\
0\end{array}$ & 14 & 100 \\
& & & & & \\
\hline
\end{tabular}

\section{KESIMPULAN}

Berdasarkan hasil penelitian tindakan kelas dan analisa data, maka dapat disimpulkan sebagai berikut:

1. Metode SAS padapembelajaran dapat meningkatkan kemampuan membaca permulaan anak usia 56 tahun di TK Taman Harapan Medan.

2. Peningkatan kemampuan membaca permulaan anak pada siklus I diperoleh kemampuan membaca permulaan anak masih rendah. Dari 14 orang anak,11 orang anak $(79 \%)$ tergolong mulai berkembang, dan 3 orang anak (21\%) tergolong berkembang sesuai harapan. Nilai rata-rata kemampuan membaca permulaan anak yaitu 48,21. Pada siklus ini kemampuan klasikal belum tercapai karena kemampuan klasikal anak pada kategori mulai berkembang.

3. Pada siklus II terjadi peningkatan yang signifikan, anak yang memiliki kemampuan membaca permulaan yaitu $36 \%$ (5 orang anak) berkembang sangat baik, $43 \%$ (6 orang anak) berkembang sesuai harapan dan (3 orang anak) $21 \%$ mulai berkembang. Nilai rata-rata kemampuan membaca permulaan anak yaitu 70,53. Dengan memberikan tindakan yang benar dan tepat seperti: media menarik dan lebih besar dan berwarna serta motivasi dan penghargaan kepada anak, mampu meningkatkan kemampuan membaca permulaan anak.

Berdasarkan kesimpulan di atas yang telah terbuktikan bahwa penerapan metode SAS, dapat meningkatkan kemampuan membaca permulaananak, maka kami sarankan hal-hal sebagai berikut:

1. Dalam kegiatan belajar mengajar guru diharapkan dapat menerapkan metode SAS sebagai suatu alternatif untuk meningkatkan kemampuan membaca permulaan anak.

2. Dengan melihat hasil pembelajaran yang dicapai, tentunya dapat dikembangkan model pembelajaran dan pendekatan media yang bervariasi, inovasi pada tema lainnya.

3. Hendaknya guru dalam menyampaikan materi selalu menggunakan alat peraga sekalipun sangat sederhana, karena akan memudahkan anak dalam penguasaan materi.

4. Untuk para guru pendidik, diharapkan kegiatan ini dapat dilakukan secara berkesinambungan dalam proses pembelajaran di dalam kelas maupun di luar kelas. 


\section{DAFTAR RUJUKAN}

Arikunto, Suharsimi, dkk. 2012. Penelitian Tindakan Kelas. Jakarta: Bumi Aksara.

Aqib.Zainal. 2011. Penelitian Tindakan Kelas. Bandung: Yrama Widya.

Firmanawaty, Sutan. 2004. 3 Langkah Praktis Menjadikan Anak Maniak Membaca. Jakarta: Puspa Swara.

Kemendiknas. 2009. Permen Nomor 58 tahun 2009 Standar Perkembangan Anak. Jakarta.

Rosni. 2016. Penerapan Metode SAS (Struktural Analitik Sintetik) Dalam Meningkatkan Kemampuan Membaca Permulaan Anak Usia 5-6 Tahun Di TK Taman Harapan Tahun Ajaran 2015/2016. Medan.

Tarigan, Irfiani.2011.Meningkatkan Keterampilan Melipat dengan Memanfaatkan Kertas Bekas Melalui Metode Demonstrasi pada Mata Pelajaran SBK di Kelas IV SD Negeri 043935 Kabanjahe. Skripsi. FIP. Unimed. 